\title{
WYBRANE ASPEKTY FUNKCJONOWANIA AKADEMICKICH INKUBATORÓW PRZEDSIĘBIORCZOŚCI W POLSCE
}

\begin{abstract}
Streszczenie
Akademickie Inkubatory Przedsiębiorczości (AIP) zapewniają unikalne środowisko dla aktywności gospodarczej w Polsce. Pojawiły się w celu dostosowania się do poszczególnych potrzeb praktyki nauczania przyszłych przedsiębiorców, a także pomagania im w podejmowaniu pierwszych kroków w zakładaniu oraz rozwijaniu własnego biznesu. Akademickie Inkubatory Przedsiębiorczości najlepiej wspomagaja przedsiębiorczość dzięki promowaniu i wspieraniu przedsiębiorczości, co prowadzi do rozwoju społeczno-gospodarczego regionu i kraju. Celem publikacji jest omówienie istoty Akademickich Inkubatorów Przedsiębiorczości oraz zaprezentowanie wybranych aspektów ich funkcjonowania jako instytucjonalnej formy rozwoju przedsiębiorczości akademickiej w Polsce.
\end{abstract}

Słowa kluczowe: przedsiębiorczość akademicka, Akademickie Inkubatory Przedsiębiorczości

\section{SELECTED ASPECTS OF ACADEMIC BUSINESS INCUBATORS IN POLAND}

\section{Summary}

Academic Business Incubators (AIP) provide a unique environment for economic activity in Poland. They were established to meet the various needs associated with practical training of future entrepreneurs and to help them take their first steps in setting up and developing their own businesses. Academic Business Incubators best support entrepreneurship by promoting and fostering entrepreneurship, leading to the socio-economic development of the region and the entire country. The aim of the paper is to discuss the essence of Academic Business Incubators and present issues of their functioning as an institutional approach to developing academic entrepreneurship in Poland.

Key words: academic entrepreneurship, Academic Business Incubators

JEL Classification: D01

\section{Wstęp}

Nowoczesna gospodarka, w znacznej mierze oparta na wiedzy połączonej z praktyka, wymusza zmiany w funkcjonowaniu uczelni wyższych w kraju. Nastawienie na praktyczne 
podejście, otwarcie na biznes oraz kreowanie zdolności do wyzwalania potencjału przedsiębiorczości wśród własnych pracowników naukowych, studentów i doktorantów są bardzo atrakcyjnym sposobem rozwoju szkół wyższych. Istotnym elementem jest równocześnie fakt, iż duża ilość absolwentów wyraża chęć prowadzenia własnej firmy po ukończeniu studiów.

Jak słusznie zauważa P. Tamowicz: przedsiebiorczosíc - innowacje - konkurencyjnosíc to tańcuch stów drisiaj czesto wisywany, kiedy jest mowa o postepie spotecznym i ekonomicznym. Towaryysza temu programy i driałania państw $i$ wspólnot ponadnarodonych zmierzajace do poprany jakości ṡycia w skali lokalnej i globalnej. Zgromadrone w trakcie realizacii dośniadcrenia uswiadamiaja decydentom i obywatelom, ze skupianie sie wytacznie na waskiej grupie zagadnien kluczonych nie gwarantuje petnego sukcesu. Obok nowych zjawisk. $i$ zagrożen oraz, zafascynowania wysokimi technologiami, niezmiennie pojawia sie crynnik. ludzki zarónno w skali jednostki (psychologiczny)), jak i calych spoteczeństw (socjologiczny) [Tamowicz, 2006, s. 5]. Wskazanie przez autora psychologicznych i socjologicznych uwarunkowań innowacyjnej przedsiębiorczości jest niezwykle cenne, ponieważ zbyt często nie docenia się ich, czy wręcz pomija. Widać to na przykład w raporcie Polskiej Agencji Rozwoju Przedsiębiorczości (PARP), który koncentruje się na prostych konstatacjach, a nie złożonych uwarunkowaniach realizacji innowacyjnej przedsiębiorczości. Stwierdza się w nim między innymi to, iż obecnie jednym z głównych czynników kreujących rozwój gospodarczy jest umiejętność tworzenia innowacji, słowem, umiejętność tworzenia, przyswajania i wykorzystywania nowej techniki i wiedzy; że współczesna gospodarka jest gospodarką, w której coraz większą rolę odgrywają innowacyjne przedsiębiorstwa, zakładane przy współudziale ośrodków akademickich na podstawie badań prowadzonych przez pracowników naukowych, studentów i doktorantów; że zmiany ekonomiczno-społeczne oraz rozwój gospodarczy w dużym stopniu oparte na wiedzy wpływają na zmiany w obszarze edukacji szkolnictwa wyższego, generując nowe formy współpracy nauki i gospodarki; że otwarcie na biznes oraz wyzwolenie potencjału przedsiębiorczości wśród własnych pracowników naukowych, studentów i doktorantów stanowią bardzo interesująca drogę rozwoju szkół wyższych w wielu krajach i regionach [Stawasz $i$ in. 2009, s. 6]. Wszystko to jest znane i słuszne, ale nie mówi nic o sposobach realizacji i przeszkodach.

\section{Istota Akademickich Inkubatorów Przedsiębiorczości}

Na przełomie ostatnich lat w Polsce można zaobserwować znaczący wzrost liczby instytucji otoczenia i wspierania przedsiębiorczości i biznesu. Jak wynika z raportu Stowarzyszenia Organizatorów Ośrodków Innowacji i Przedsiębiorczości w Polsce, w drugiej połowie 2007 roku zidentyfikowano 694 tego typu jednostki. Celem porównania, w 2002 roku było ich poniżej 400, natomiast w 1996 roku poniżej 200. Do tych instytucji można zaliczyć: centra transferu technologii, inkubatory, preinkubatory, a także parki naukowo-technologiczne oraz instytucje szkoleniowo-doradcze. Rozwój tego typu instytucji bezpośrednio można oceniać w postaci udanych wdrożeń pomysłów bizneso- 
wych w struktury rynkowe. Główny nacisk kładzie się na stworzenie odpowiednich warunków do współpracy między sektorem przedsiębiorstw a nauki oraz zapewnienie szybkiego przepływu wiedzy lub techniki z uczelni do biznesu.

Droga rozwoju szkół wyższych w znacznym stopniu staje się uzależniona od kreowania zdolności do wyzwalania potencjału przedsiębiorczości wśród własnych pracowników naukowych, studentów i doktorantów. Zdecydowanie zauważa się aktywność uczelnianych centrów transferu technologii oraz biur karier, które odgrywają istotną rolę w kształceniu podstaw przedsiębiorczości wśród studentów oraz absolwentów szkół wyższych. Jednak zarówno biura karier, jak i centra transferu technologii nie zaspokajają wszystkich potrzeb zgłaszanych przez studentów i absolwentów, a dotyczących wsparcia w podejmowaniu działalności gospodarczej. Tymczasem potencjał studentów, absolwentów i pracowników uczelni jest ogromny, gdyż: prz̨edsiębiorczość to narodowa cecha Polaków, a Polska to kraj wielkich możliwości. Polacy wygrywaja światowe konkursy informatyczne oraz wspóttworzq najwieksze projekty biznesowe i badawcze, pracuja w międzynarodowych zespołach naukowych, sq znani ze swojej pracowitości i kreatywności. Wedtug Eurobarometru, prawie 50\% młodych Polaków zamierza stworzyć w perspektywie 5 lat wlasna firme, co stawia nas pod tym wagledem w czołówce światowej [http://www.przedsiebiorca.pl].

Jednym z podmiotów, łączącym biznes z uczelniami wyższymi, są Akademickie Inkubatory Przedsiębiorczości. Często są one miejscem, gdzie swoje pierwsze kroki stawiaja późniejsze przedsiębiorstwa, osiągające sukcesy na arenie międzynarodowej. Zgodnie z Ustawa Prawo o szkolnictwie wy $\dot{s} s y m$, powołująca do istnienia te jednostki, Akademicki Inkubator Przedsiębiorczości definiuje się jako jednostkę prowadzoną przez uczelnię wyższą: w celu lepszego wykorzystania potencjału intelektualnego i technicznego uczelni, oferujaca wsparcie driałalności gospodarczej środowiska akademickiego lub pracowników uczelni $i$ studentów bedacych przedsiębiorcami [Ustawa z dnia 27 lipca 2005 r. Prawo o szkolnictwie wy żsym, 2005].

Akademickie Inkubatory Przedsiębiorczości (AIP) głównie skupiają się na fazie preinkubacji. Powstają w otoczeniu szkół wyższych, a ich celem jest kształtowanie miejsca do rozwoju przedsiębiorstw i nabierania przez nie doświadczenia, tak aby później mogły samodzielnie funkcjonować na rynku. Jednym z założeń AIP jest zapewnienie studentom połączenia wiedzy teoretycznej z praktyczną oraz sposobności sprawdzenia się w biznesie. Celem inkubatora jest umożliwianie zakładania własnej firmy przy minimalnych nakładach finansowych. Funkcjonowanie w AIP jest najprostszym sposobem na zdobywanie doświadczenia w zakresie: zarządzania firmą, nawiązywania wspó1pracy biznesowej oraz wymiany poglądów [Siemieniuk, 2007, s. 212].

Akademickie Inkubatory Przedsiębiorczości są jednostkami powstającymi przy ośrodkach akademickich w całym kraju. Ich idea jest stworzenie idealnych warunków do rozwoju pomysłów biznesowych. Są połączeniem wiedzy reprezentowanej przez kadrę naukową szkoły wyższej oraz wiedzy praktycznej, dotyczącej funkcjonowania firm w Polsce. Misją AIP jest: stworzenie warunków do rozwoju innowacji oraz do komercjalizacji pomysłów opartych na wiedzy i nowych technologiach, wzmocnienie potencjału przedsiębiorców oraz jego wykorzystanie. Założeniem inkubatorów jest przekazanie studentom kompleksowej wiedzy praktycznej, którzy po ukończeniu studiów dysponują ogromną wiedzą teoretyczna, ale tę z trudnością transferują do praktyki. Celem inkubatora jest 
umożliwienie założenia im własnej firmy, przy minimalnych nakładach finansowych. Działanie w inkubatorze jest sposobem na zdobywanie przez studentów doświadczenia w zakresie: praktyki gospodarczej, wymiany poglądów i nawiązywania kontaktów biznesowych. Akademickie Inkubatory Przedsiębiorczości to jedno z przedsięwzięć wspierających młodych przedsiębiorców w działaniach zmierzających do rozwinięcia ich zainteresowań i usamodzielnienia się pod względem finansowym. Inkubator przedsiębiorczości jest jednym z nowych sposobów rozwoju przedsiębiorczości i ułatwia firmie pokonywanie sytuacji kryzysowych na swej drodze. Idea inkubowania nawiązuje do faz rozwojowych, które przechodzi każde nowo tworzone przedsiębiorstwo.

Akademickie Inkubatory Przedsiębiorczości to największa w Polsce organizacja promująca przedsiębiorczość wśród młodych ludzi. Akademickie Inkubatory Przedsiębiorczości funkcjonują na podstawie procedur systemu zarządzania jakością PN-EN ISO 9001:2001, sa wpisane do Krajowego Systemu Usług oraz Krajowej Sieci Innowacji. Sa również największą siecią akademickich inkubatorów przedsiębiorczości w Europie, świadczących usługi proinnowacyjne. To pionierska praca ponad 150 osób, podążających za jasnym przesłaniem i ideą - zmieniać przedsiebiorcze oblicze naszego kraju, dać szanse mtodym oraz kreowaćprzedsiebiorczość jako narodowa ceche Polakón [Materialy wewnetržne Fundacji...]. Działania osób, zaangażowanych w projekt AIP, doprowadziły do stworzenia i funkcjonowania inkubatorów na najlepszych uczelniach w całej Polsce. Stało się to pod egida fundacji AIP. Stworzony został pakiet innowacyjnych usług dla osób, które chcą skorzystać z usług inkubatora, od rozliczania księgowego i finansowego firmy, poprzez pisanie umów i udzielanie porad prawnych, aż do świadczenia usług o wysokim potencjale rynkowo-technologicznym, w tym także przyznawania dotacji i pożyczek. Akademickie Inkubatory Przedsiębiorczości powstały z inspiracji trzech przyjaciół, studentów warszawskich uczelni, Dariusza Żuka, Jacka Aleksandrowicza i Mariusza Turskiego. W 2001 roku przy Business Centre Club założyli oni organizację studencką o nazwie Studenckie Forum BCC (SF BBC), która przez kilka lat pod ich przewodnictwem objęła 15 regionów i skupia dziś ponad 800 przedsiębiorczych studentów z całej Polski, stanowiąc obecnie największą polską organizację studencka, promująca przedsiębiorczość. Celem SF BCC jest popularyzacja przedsiębiorczości oraz działań na rzecz zmian w prawie polskim, które doprowadziłyby do powszechnego zakładania firm przez młode osoby. Na bazie SF BCC w 2004 roku została powołana w Warszawie Fundacja Akademickie Inkubatory Przedsiębiorczości, a jej celem była organizacja sieci AIP na uczelniach całej Polski. Koncepcja sieci AIP okazała się dużym sukcesem młodych ludzi, który mógł zostać osiagnięty dzięki zaangażowaniu grupy entuzjastów przedsiębiorczości, ale przede wszystkim dzięki wypracowanemu w AIP, innowacyjnemu na skalę europejska, modelowi preinkubacji (w przeciwieństwie do podobnych instytucji europejskich, niepolegającemu tylko na wynajmie powierzchni). Natomiast w jego ramach najłatwiej, najszybciej i najmniej ryzykownie w Europie każda młoda osoba może zacząć prowadzenie praktycznie każdego biznesu [Materialy wewnetržne Fundacji...].

Akademickie Inkubatory Przedsiębiorczości to specyficzny typ inkubatora przedsiębiorczości, który jest traktowany zarówno jako przedłużenie procesu dydaktycznego mającego na celu przygotowanie do stworzenia przedsiębiorstwa oraz praktycznego dzia- 
łania na rynku, jak i procesu weryfikacji zdobytej wiedzy i umiejętności. Inkubatory tworzone w otoczeniu uczelni wspieraja studentów i pracowników naukowych w rzeczywistych działaniach rynkowych. Realizowane w nich działania są zorientowane na edukację przedsiębiorczości oraz komercjalizację nowych produktów i technologii, będących efektem prac badawczo-rozwojowych prowadzonych na uczelni [Guliński, Zasiadły, 2005, s. 29].

Głównym celem Fundacji AIP jest szerzenie postaw przedsiębiorczych w środowisku akademickim. Działanie firmy w strukturze AIP daje możliwość zbadania rynku i osiagania pozytywnych wyników ekonomicznych. Inkubatory w istotny sposób pomagają w usunięciu barier związanych z tworzeniem oraz rozwojem małych i średnich przedsiębiorstw. Nowo powstałe firmy mają dostęp do usług, dzięki którym mogą uniknąć nadmiernego zatrudnienia i zakupu środków trwałych, na które niejednokrotnie nie stać przedsiębiorcy. Ponadto, przedsiębiorstwa uzyskują fachowe doradztwo. Większość inkubatorów przedsiębiorczości zostało utworzonych jako inicjatywa fundacji, stowarzyszenia czy też agencji rozwoju regionalnego.

Jak wskazuje K. Matusiak, właściwa adaptacja inkubatora przez szkołę wyższą może przynieść szereg korzyści tak uczelni, jak i przedsiębiorcom, do których należą:

- uatrakcyjnienie oferty edukacyjnej;

- $\quad$ poprawa relacji z otoczeniem i lokalnym biznesem;

- $\quad$ zwiększenie dochodów ze współpracy i transferu technologii do firm absolwenckich;

- $\quad$ zwiększenie zamówień oraz sponsorowanie działalności badawczej;

- poprawa wizerunku uczelni;

- $\quad$ pozyskiwanie dodatkowych środków z programów wspierania przedsiębiorczości technologicznej;

- dodatkowe możliwości dochodów dla studentów, pracowników naukowych i inżynieryjno-technicznych;

- obniżka kosztów założycielskich firmy;

- dostęp do doradztwa i informacji;

- $\quad$ efekty demonstracji w postaci utrwalenia się przekonania, że dane rozwiązanie jest dostępne dla każdego;

- $\quad$ koncentracja publicznych form wsparcia dla młodych firm [Matusiak, 2001, s. 187-196].

Do specyficznych korzyści, istotnych z punktu widzenia studentów i doktorantów, zalicza się:

- $\quad$ zdobycie niezbędnej wiedzy i doświadczenia związanych z prowadzeniem własnej działalności gospodarczej;

- obniżkę kosztów założenia firmy;

- dostęp do doradztwa i informacji;

- $\quad$ środowisko sprzyjające biznesowi;

- $\quad$ efekty demonstracji - ,ja też mogę spróbować”;

- $\quad$ koncentrację różnych, publicznych form wsparcia dla małych przedsiębiorstw;

- zdobycie doświadczenia i praktycznej wiedzy o rynku [Matusiak, Zasiadły, 2005, s. 30]. 
Biorąc pod uwagę typ organizatorów i ich specyfikę organizacyjną, wszystkie preinkubatory działające w Polsce można podzielić na trzy grupy:

- preinkubatory działające przy Fundacji Akademickie Inkubatory Przedsiębiorczości (FAIP);

- Akademickie Inkubatory działające w ramach państwowych szkół wyższych, w dużej mierze powiązane z uczelnianymi biurami karier oraz ośrodkami transferu technologii;

- Preinkubatory działające w ramach parków i inkubatorów technologicznych oraz organizacji studenckich [Ośrodki innowacji w Polsce, 2009, s. 95-96].

Istotnym celem Fundacji Akademickich Inkubatorów Przedsiębiorczości jest popularyzacja postaw przedsiębiorczych w środowisku akademickim. Firma, zwana Start-Up, w strukturze Akademickich Inkubatorów Przedsiębiorczości pozwala na zbadanie rynku i osiągnięcie pozytywnych wyników ekonomicznych. Firmy, znajdujące się w strukturze AIP, otrzymują dostęp do usług, dzięki którym mogą uniknąć wielu niepowodzeń w początkowej fazie rozwoju. Dodatkowo, beneficjenci uzyskuja wsparcie merytoryczne ze strony ekspertów współpracujących z danymi AIP. Większość inkubatorów przedsiębiorczości została utworzona jako inicjatywa fundacji, stowarzyszenia czy te $\dot{z}$ agencji rozwoju regionalnego.

Akademickie Inkubatory, działające w strukturach państwowych szkół wyższych, w znacznej części są powiązane z uczelnianymi ośrodkami transferu technologii lub biurami karier. Ten rodzaj AIP działa w formie samodzielnego projektu i stanowi dopełnienie działań w zakresie programu wsparcia innowacji i transferu technologii. Projekty, wybrane pod kątem wymogu innowacyjności przedsięwzięcia, zdobywaja pomoc z szerokim spektrum wsparcia procesu założycielskiego, takim jak: asysta w transferze technologii, doradztwo i szkolenia, dostęp do baz danych i kontaktów międzynarodowych oraz informacja i pomoc w zakresie dostępu do krajowych i zagranicznych grantów oraz funduszy ryzyka (venture capital). Uczelniane preinkubatory mogą swobodnie rozwijać współpracę z innymi jednostkami o charakterze dydaktycznym i naukowobadawczym. Mają także lepszy dostęp do infrastruktury szkoły wyższej i zasobów kadrowych. Sama szkoła wyższa uwiarygodnia ich działalność, m.in. normując przepływy finansowe związane z realizacją zewnętrznych projektów. Wadą tych inkubatorów jest dość powszechna, uczelniana biurokracja oraz niezrozumienie dla idei realizowanej działalności [Matusiak, Zasiadły, 2005, s. 32].

Preinkubatory, funkcjonujące w parkach i inkubatorach technologicznych oraz w ramach organizacji studenckich, stanowią poszerzenie programów wsparcia innowacyjnej przedsiębiorczości realizowanych w parkach technologicznych i inkubatorach. W wyniku ich działalności powstają nowe firmy typu spin-off, dla których park generuje środowisko optymalne do dalszego rozwoju. Jednocześnie w tym miejscu zamyka się pełne koło inkubacji biznesu, począwszy od preinkubatora, przez możliwości rozwoju firmy w inkubatorze technologicznym, a na perspektywie inwestycji w parku technologicznym kończąc. Działalność w takim inkubatorze zaspokaja potrzeby uzależnione od etapu rozwoju w jednym miejscu, a zarazem umożliwia rozwój trwałych relacji sieciowych między firmami a instytucjami naukowymi [Innowacje i transfer technologii..., 2008, s. 255]. 
Akademickie Inkubatory Przedsiębiorczości ułatwiają młodym osobom start w biznesie przez, innowacyjny na skalę europejską, sposób na prowadzenie firmy na zasadzie pionów AIP (w programie preinkubacji). Dzięki takiemu rozwiązaniu, nie ma konieczności zakładania własnej działalności gospodarczej, co obniża koszty biurokracji, jak również ryzyko młodych przedsiębiorców, pozwalając im skoncentrować się na rozwijaniu swojej firmy. Zakładając firmę w AIP, młody człowiek uzyskuje pełne wsparcie w zakresie prowadzenia księgowości swojej firmy, ale jednocześnie nie figuruje w rejestrach jako osoba prowadząca indywidualną działalność gospodarczą, w związku z czym nie ma obowiazku opłacania składki ZUS, a także nie blokuje sobie możliwości korzystania z programów pomocowych, przeznaczonych dla osób nieprowadzących działalności gospodarczej. Uczestnik programu AIP otrzymuje równocześnie pomoc w zakresie obsługi prawnej. Każda firma, działająca w programie AIP, zarazem otrzymuje do dyspozycji swoje indywidualne konto bankowe.

Jednym z podstawowych elementów każdej firmy na początku jej działalności jest jej promocja. Niewiele firm, założonych przez młodych biznesmenów, dysponuje odpowiednim budżetem promocyjnym. Akademickie Inkubatory Przedsiębiorczości z racji swojej działalności oraz niezależności finansowej są w stanie promować swoich podopiecznych za sprawą mediów lokalnych i ogólnopolskich.

\section{Charakterystyka funkcjonowania Akademickich Inkubatorów Przedsiębiorczości w Polsce}

Historia Akademickich Inkubatorów Przedsiębiorczości sięga 2004 roku. Stanowią one kontynuację działalności Studenckiego Forum BCC, powołanego w 2001 roku przy największej organizacji pracodawców - Business Centre Club. W szybkim tempie stały się jedną z największych organizacji studenckich w Polsce, zrzeszająca 15 oddziałów regionalnych. Obecnie funkcjonuja przy 34 najlepszych uczelniach w Polsce. Akademickie Inkubatory Przedsiębiorczości gromadzą młodych, dobrze wykształconych ludzi, z ogromnym potencjałem chęci poszerzenia swojej wiedzy teoretycznej o aspekty wiedzy praktycznej.

Środowisko akademickie właściwie warunkuje realizacje projektu Akademickich Inkubatorów Przedsiębiorczości, gdyż jest ono dobrą ofertą wsparcia studentów w praktycznych działaniach rynkowych, w wyniku ciagle rozwijanej i upowszechnianej wiedzy. Preinkubator, działający przy szkole wyższej, stwarza szczególne możliwości wzrostu nowo utworzonych firm dzięki dostępowi do:

- uczelnianych laboratoriów;

- $\quad$ wiedzy profesorów wyspecjalizowanych w wielu dziedzinach;

- doradztwa technologicznego.

Akademickie Inkubatory Przedsiębiorczości są zaliczane do najbardziej dynamicznych ośrodków innowacyjności w ostatnich latach o dużym potencjale rozwojowym, mimo że dyskusja o potrzebie rozwoju przedsiębiorczości akademickiej w Polsce jest opóźniona o czterdzieści lat w stosunku do USA [Matusiak, 2010, s. 59]. Organizacji Akademickich Inkubatorów Przedsiębiorczości przysłużył się konkurs zorganizowany 
przez Ministerstwo Gospodarki i Pracy w marcu 2004 roku na „Akademickie Inkubatory Przedsiębiorczości". Całe zaplecze legislacyjne, sprzyjające szybkiemu rozwojowi Akademickich Inkubatorów Przedsiębiorczości, umożliwiła Ustawa z. dnia 27.07.2005 roku Prawo o sžkolnictwie wyższym, a w szczególności artykuł 86. Ustawy, który stanowi, że: w celu lepszego wykorzystania potencjatu intelektualnego i technicznego uczelni oraz transferu wyników prac naukowych do gospodarki, uczelnie moga prowadzic akademickie inkubatory przedsiebiorczości oraz. centra transferu technologii. Powyższy zapis służy rozwojowi całej uczelnianej infrastruktury przedsiębiorczości, pozostawiając do wyboru formę organizacyjno-prawną dostosowaną do warunków konkretnej uczelni (jednostka ogólnouczelniana, spółka handlowa czy też fundacja) [Matusiak, 2010, s. 60].

Zakłada się, że sprawne działanie Akademickiego Inkubatora Przedsiębiorczości jest efektem współdziałania przede wszystkim następujących grup ludzi:

- jednostki zarządzającej, prowadzącej działalność operacyjno-administracyjna;

- $\quad$ zespołu doradczego, w skład którego wchodzą osoby odpowiedzialne za usługi szkoleniowe i doradcze;

- $\quad$ rady programowej będącej ciałem doradczo-kierowniczym.

Równie ważnym elementem, mającym wpływ na odniesienie sukcesu przez dany inkubator, jest odpowiedni poziom jego współpracy z: otoczeniem lokalnym, ośrodkami innowacji i przedsiębiorczości oraz instytucjami finansowymi [Czop, Lewandowska, s. 2].

Cała działalność Akademickich Inkubatorów Przedsiębiorczości oraz jej związek z procesem dydaktycznym uczelni wciąż są niedostateczne. Przedsiębiorczość akademicka jest traktowana jako dodatkowe zajęcie wykraczające poza tok zajęć dydaktycznych. Na większości uczelni zainteresowanie inkubatorami ze strony władz jest niewielkie, co pozostawia je na marginesie zadań statutowych uczelni. Niektórzy dyrektorzy inkubatorów uczelnianych wyrażają opinię, że lepsze warunki i większą chęć pomocy gwarantują szkoły niepubliczne. Z kolei, właśnie na renomowanych uczelniach państwowych, a nie na niepublicznych, są studenci charakteryzujący się większym zaangażowaniem [Matusiak, 2010, s. 67].

Niemniej zainteresowanie przedsiębiorczością akademicką jest widoczne oraz szanse na rozwój programów preinkubacji są dobrą oznaką zmian zachodzących w szkolnictwie wyższym. Rozwój przedsiębiorczości akademickiej jest jednym z istotnych elementów polityki innowacyjności państwa, który przyczynia się do utrzymania gospodarki na ścieżce szybkiego rozwoju, a Akademickie Inkubatory Przedsiębiorczości są zaliczane do tego typu procesów. Wobec czego, ich rozwój powinien leżeć zarówno w interesie państwa, jak i poszczególnych uczelni oraz studentów, ponieważ w przyszłości wiąże się to z korzyściami wszystkich wymienionych podmiotów.

Akademickie Inkubatory Przedsiębiorczości są najnowocześniejszym przykładem na rozwój kapitału ludzkiego. To właśnie dzięki ambicji, pracy zespołowej, aktywności $\mathrm{i}$ innowacyjności ludzi kreują one znakomite miejsce do wszelkiej pomocy ułatwiającej prowadzenie firmy na zasadzie pionu Akademickiego Inkubatora Przedsiębiorczości, bez konieczności zakładania własnej działalności gospodarczej. Taka decyzja, podjęta przez początkującego przedsiębiorcę, ogranicza m.in.: koszty, ryzyko i całą biurokrację. 
Za sprawą odpowiednio dostosowanego prawa, zakładający firmę w ramach Akademickich Inkubatorów Przedsiębiorczości w pełni może korzystać z osobowości prawnej AIP, a zakładana firma będzie funkcjonować formalnie jako komórka w ramach organizacji AIP. Pozwala to młodemu przedsiębiorcy zaoszczędzić czas związany z oczekiwaniem na założenie działalności gospodarczej jako podmiotu, jak również minimalizuje środki potrzebne na jej otwarcie. Do głównych zalet prowadzenia firmy w ramach AIP można zaliczyć to, że osoba prowadząca działalność nie figuruje w rejestrach jako osoba prowadząca indywidualną działalność gospodarczą, a także nie ma obowiązku opłacania składek ZUS [http://www.inkubatory.pl/pl].

Ponadto, zaletą działalności w ramach AIP jest uwiarygodnienie osoby prowadzącej firmę, dzięki występowaniu w jej imieniu przez Fundację z siedzibą w stolicy państwa, wspartą działalnością kilkudziesięciu oddziałów w całym kraju, których obrót roczny sięga kilkunastu milionów złotoch [www.inkubatory.pl/pl].

Firmy założone w ramach AIP otrzymują również wsparcie księgowe. Wszystkie dokumenty księgowe $z$ danego miesiąca rozliczeniowego są weryfikowane przez pracowników inkubatorów, a następnie przesyłane do Działu Finansowo-Księgowego Fundacji AIP w Warszawie w celu zaksięgowania. Umożliwia to sporządzenie wszystkich dokumentów zgodnie z obowiązującymi przepisami. Akademickie Inkubatory Przedsiębiorczości dbają o to, aby przedsiębiorca mógł skupić się na własnym biznesie bez ryzyka popełnienia błędu w rozliczeniach finansowych oraz uniknął zbędnej biurokracji w urzędach. Funkcjonowanie obsługi księgowej zaprojektowane jest tak, by osoba prowadząca działalność w AIP mogła nauczyć się procedur i zasad związanych z obrotem dokumentami księgowymi od podstaw, aż po wszelkie bardziej złożone procedury dotyczące prowadzenia wybranej przez niego działalności [http://inkubatory.pl/pl/ proces-zakadania-firmy-w-aip/co-daje-aip].

Obsługa prawna to kolejny aspekt wspomagający funkcjonowanie firmy przy Akademickich Inkubatorach Przedsiębiorczości. Osoba prowadząca firmę ma do dyspozycji prawników z Działu Prawnego AIP. Dzięki ich pomocy, zawieranie kontraktów czy też podejmowanie decyzji w sprawach spornych nie jest objęte ryzykiem. Działanie pod osobowościa prawna AIP to podstawowy element zapewniający bezpieczeństwo działania przedsiębiorcom - w sytuacji spornej (których w biznesie nie brakuje) osoba taka nie jest pozostawiona „sama sobie” i może liczyć na wsparcie Fundacji w jej rozwiązaniu [http://www.inkubatory.pl/pl].

Co więcej, firmy działające w ramach Akademickich Inkubatorów Przedsiębiorczości mają do dyspozycji swoje indywidualne konto bankowe, na które są przelewane wszystkie uzyskane dochody i tym samym gwarantuje się bezpieczeństwo finansowe niedoświadczonym osobom.

Niewatpliwie, każda firma, rozpoczynająca swoją działalność, powinna prowadzić odpowiednią promocję, aby zaistnieć na rynku. Jednak nie zawsze małe firmy angażuja się w tego typu przedsięwzięcia, a jest to najczęściej spowodowane małym budżetem promocyjnym. Akademickie Inkubatory Przedsiębiorczości są w stanie promować swoje firmy poprzez media, zarówno lokalne, jak i ogólnopolskie [http://www.inkubatory.pl/pl]. 
Za sprawą wyspecjalizowanych pracowników Fundacji AIP, firmy mogą więc liczyć także na profesjonalną pomoc związaną z prowadzeniem działalności w wyniku profesjonalnego marketingu, wykorzystania wiedzy o public relations itp.

Oprócz wyżej wymienionych przykładów wspomagania i funkcji oddziaływania Akademickich Inkubatorów Przedsiębiorczości na rozwój kapitału ludzkiego nowo zakładanych firm, można jeszcze wyróżnić:

- dostęp do przestrzeni biurowej;

- $\quad$ dostęp do sal dydaktycznych;

- $\quad$ pomoc w pozyskaniu kapitału na dalszy rozwój;

- $\quad$ organizowanie szkoleń i warsztatów z zakresu tworzenia i zarządzania własna firma;

- działalność proinnowacyjną dzięki pomocy w nawiązywaniu kontaktów gospodarczych.

Wszystko, o czym była mowa wyżej, powoduje, że w chwili obecnej coraz więcej osób, pragnących założyć własną działalność gospodarcza, rozważa jej rozpoczęcie właśnie w Akademickich Inkubatorach Przedsiębiorczości. Na pewno wiąże się to z bogatymi zasobami, jakie AIP udostępnia firmom. Ważnym czynnikiem jest fakt, że kontynuowanie działalności w inkubatorze przedsiębiorczości zwiększa współczynniki funkcjonalności firmy na rynku, co potwierdzają liczne badania. Ponadto, niektóre inkubatory przedsiębiorczości są objęte specjalnymi programami przedsiębiorczości osób niepełnosprawnych, które mają na celu likwidację barier fizycznych i środowiskowych.

Wielu przedsiębiorców poszukuje zabezpieczeń pozwalających utrzymać się na konkurencyjnym rynku, pomimo odczuwalnego dla wielu kryzysu światowego. Akademickie Inkubatory Przedsiębiorczości są jednym z nielicznych, możliwych rozwiązań, które w pełni wspomagają nowo powstające, jak również już działające podmioty gospodarcze. To dzięki Akademickim Inkubatorom Przedsiębiorczości rozwój kapitału ludzkiego jest tak znaczny, dostępny i popularny.

W ramach Akademickich Inkubatorów Przedsiębiorczości osoba prowadząca firmę, zwana beneficjentem, otrzymuje następujące świadczenia:

- prowadzenie księgowości firmy;

- kompleksowa pomoc prawna;

- dostęp do pomieszczeń biurowych;

- możliwość otrzymania środków na funkcjonowanie firmy;

- $\quad$ szereg szkoleń podnoszących efektywność zarządzania firmą;

- opiekę ekspercką;

- $\quad$ pomoc w tworzeniu marki firmy;

- $\quad$ promocję firmy na portalu: www.inkubatory.pl [http://www.inkubatory.pl/pl].

Funkcjonowanie w ramach Akademickich Inkubatorów Przedsiębiorczości pozwala także na inne rodzaje pomocy, m.in. na:

- prawo posługiwania się znakiem Akademickiego Inkubatora Przedsiębiorczości;

- $\quad$ pomoc w promocji i reklamie dzięki agencjom marketingowym;

- organizację spotkań biznesowych i pomoc w poszukiwaniu partnerów handlowych; 
- $\quad$ organizację konferencji, targów promujących firmy w AIP [http://www.inku batory.pl/pl].

Istotną kwestią jest fakt, iż coraz więcej firm działających na rynku jest zainteresowanych współpracą z Akademickimi Inkubatorami Przedsiębiorczości, a co za tym idzie, współpracą z podmiotami działającymi w ramach AIP. Ze względu na szybki wzrost liczby firm działających pod egidą inkubatorów duże korporacje zauważają w młodych przedsiębiorcach ważna grupę odbiorców swoich usług. Skumulowanie ponad 1200 podmiotów działających w obrębie Fundacji AIP spowodowało, iż młodzi przedsiębiorcy moga liczyć na profity wynikające z korzystania z usług dużych przedsiębiorstw. W tym celu utworzono specjalny program B4B.

Driatajac w ramach Akademickich Inkubatorów Przedsiębiorczości, przedsiębiorcy uzyskuja dostęp do ustug oraz zniżek zarezerwowanych do tej pory jedynie dla przedsiebiorstw o ugruntowanej pozycji na rynku. Drieki rozbudowanej sieci inkubatorów, zlokalizowanych na kluczowych polskich uczelniach, partnerzy biznesowi z. zainteresowaniem praystepuja do wspótpracy pray tworzeniu pakietu Benefits4Business. Założeniem pakietu korzyści jest stałe rozbudowywanie portfela rabatón $i$ dodatkowych świadczeń dla beneficjentów AIP [http://inkubatory.pl/pl/proces-zakadania-firmyw-aip/co-daje-aip].

Obecnie dla osób prowadzących działalność w ramach sieci AIP są dostępne m.in. następujące usługi i rabaty firm wspierających młody biznes:

- Orange - abonament telefoniczny na preferencyjnych warunkach;

- Vision - opieka medyczna - wygodny dostęp do opieki medycznej;

- $\quad$ Ideo - pozycjonowanie stron www - specjalne pakiety usług;

- WebFlow - system do obsługi faktur - dostęp do innowacyjnego systemu rozliczeniowego;

- DPD Polska - usługi kurierskie - preferencyjne ceny na usługi;

- Dotpay - bezpieczne płatności internetowe - dostęp do innowacyjnego systemu płatności;

- Platnosci.pl - bezpieczne płatności internetowe - dostęp do innowacyjnego systemu płatności;

- $\quad$ Tech Data - hurtownia sprzętu IT - dostęp do najniższych cen sprzętu IT;

- Action - hurtownia sprzętu IT - dostęp do najniższych cen sprzętu IT;

- Wydawnictwo Harvard Business Review Polska - dostęp do bezpłatnych egzemplarzy magazynu;

- Makro - hurtownia samoobsługowa - dostęp do hurtowni [Materiały promocyjne AIP].

\section{Podsumowanie}

Podsumowując, można stwierdzić, że przedsiębiorczość akademicka oparta na innowacjach to podstawowy element polityki innowacyjnej państwa. Wymaga więc opracowania odpowiednich aktów prawnych oraz stworzenia właściwych uregulowań. Przeorientowanie uczelni na współpracę ze środowiskiem gospodarczym to proces długotrwały, wymagający również zmian mentalnościowych społeczności akademickiej 
i odpowiednich regulacji wewnątrzuczelnianych. Transfer wiedzy z nauki do biznesu będzie sprawniejszy, gdy zostanie zapewnione wsparcie zarówno na szczeblu krajowym, jak i regionalnym oraz państwowym. Wyróżnione w literaturze czynniki, mające korzystny wpływ na sprawną współpracę przedsiębiorstw i uczelni, to, obok bezpośredniego wsparcia finansowego, transferu technologii, kontaktów biznesowych, także właściwa infrastruktura [Siemieniuk, 2016, s. 156].

Akademickie Inkubatory Przedsiębiorczości umożliwiają rozwój aktywności gospodarczej w Polsce, zapewniając realizację innowacyjnych pomysłów w ramach samodzielnej lub wspomaganej działalności gospodarczej, są jednocześnie szansą na efektywny transfer wiedzy i technologii do gospodarki w zakresie tworzenia Start-Up'ow.

Głównym założeniem Akademickich Inkubatorów Przedsiębiorczości jest ułatwianie młodym osobom rozpoczęcia działalności gospodarczej i pomoc w jej rozwijaniu. Akademickie Inkubatory Przedsiębiorczości dzięki dużemu spektrum świadczonych usług oraz możliwości funkcjonowania na zasadzie pionu fundacji pozwalają maksymalnie skoncentrować się osobie prowadzącej własny biznes w AIP na tym, aby prowadzona przez nią firma działała możliwie najprężniej, rozwijała się i przynosiła jak największe korzyści finansowe. Beneficjent AIP nie musi troszczyć się o kwestie techniczne dotyczące prowadzenia swojej działalności gospodarczej oraz nie obawiać się barier istniejących na rynku.

Powołanie Akademickiego Inkubatora Przedsiębiorczości nastręcza wielu problemów. Jednym z nich sa procedury prawne, innym - środki finansowe związane $z$ miejscem lokalizacji. Do jego sprawnego działania jest przecież niezbędne właściwe wyposażenie inkubatora. Dostosowanie zaś jakiegoś lokalu do potrzeb inkubatora pociaga za soba konieczność ponoszenia kosztów jego wyposażenia, m.in. w podstawowe umeblowanie i urządzenia techniczne. Pod względem ,infrastruktury” dobry inkubator powinien spełniać następujące warunki:

- położenie w pobliżu uczelni lub w miejscu o łatwym dostępie dla studentów;

- $\quad$ wyposażenie w środki łączności;

- $\quad$ wyposażenie w Internet (szybki przekaz informacji) [Inkubator instrumentem rozpijania préedsiębiorczości studentón, 2006, s. 119].

Lokalizacja AIP w ośrodkach akademickich sprzyja bliższemu kontaktowi studenta $z$ daną instytucją. W sytuacji braku środków finansowych na wynajem lokalu, o pomoc można wystapić do władz uczelni. Posiadanie samodzielnego lokum pozwala na spójne zarządzanie inkubatorem, służy spoistości grupy i jednolitemu szkoleniu jej uczestników. Funkcjonowanie w dobrych warunkach przyczynia się do skuteczniejszego prowadzenia szkoleń, seminariów czy wykładów. Od uczelni można równocześnie otrzymać wsparcie w postaci pokrycia kosztów eksploatacji. Wadą takiego rozwiązania jest przede wszystkim wydłużenie procesu podejmowania decyzji, spowodowane obiegiem dokumentów, złożonym zakresem kompetencji itp., co zmniejsza elastyczność działania.

Innym sposobem na rozwiązanie wskazanych problemów jest przyłączenie preinkubatora do funkcjonującej już organizacji o podobnym charakterze. W każdej miejscowości znajdują się różne stowarzyszenia czy fundacje, które działają na rzecz pożytku publicznego. Niektóre z nich zajmują się promocją przedsiębiorczości lub zwalczaniem bezrobocia wśród ludzi młodych, co pokrywa się z zadaniami Akademickich 
Inkubatorów Przedsiębiorczości. Niewątpliwie, wzrost poziomu przedsiębiorczości studentów przyczynia się do spadku bezrobocia w tej konkretnej grupie. Tak więc, korzyści w przypadku zorganizowania współpracy z takimi organizacjami są obustronne. Stowarzyszenie już działające rozszerza zakres swojej działalności oraz pozyskuje dodatkowy kapitał ludzki, a w następstwie tego dostęp do nowych pomysłów i rozwiązań. Preinkubator natomiast, oprócz pomieszczenia, zyskuje dostęp do kapitału finansowego oraz sieci powiązań z instytucjami publicznymi i firmami.

Tworząc inkubator akademicki, należy uwzględnić pracowników szkoły wyższej. Realizację zadań inkubatora nadzoruja pracownicy uczelni, którzy w razie problemów wspierają studentów działających w takim inkubatorze. Przyjmuje się, że studenci działający w preinkubatorach nie powinni otrzymywać wynagrodzenia za swoją pracę, a jedynie zwrot poniesionych wydatków. Młodzież czerpie wiele korzyści ze współpracy z AIP, np. udział w szkoleniach, które w przyszłości mogą ułatwić jej funkcjonowanie na rynku pracy oraz umożliwić wykorzystanie nabytej wiedzy teoretycznej w praktyce.

\section{Literatura}

Czop K., Lewandowska J., 2006, Akademickie Inkubatory Przedsiebiorczości - funkcje i obszary dzৃiałalności, Naukowe Koło Zarządzania Przedsiębiorstwem, Katedra Organizacji Przedsiębiorstwa, Politechnika Lubelska, Lublin.

Guliński J., Zasiadły K., 2005, Præedsiębiorczośc Akademicka w Polsce - stan obecny, [w:] Innowacyjna przedsiębiorczość akademicka - swiatowe dośniadczenia, J. Guliński, K. Zasiadły (red.), Polska Agencja Rozwoju Przedsiębiorczości, Warszawa.

http://inkubatory.pl/pl/proces-zakadania-firmy-w-aip/co-daje-aip (data wejścia: 09.03.2017).

http://www.inkubatory.pl/pl (data wejścia: 09.03.2017).

http://www.przedsiebiorca.pl (data wejścia: 09.01.2017).

Inkubator instrumentem rozpijania przedsiebiorczości studentón, 2006, S. Jankiewicz (red.), Wydawnictwo Sorus, Poznań.

Innowacje i transfer technologii. Stownik pojéc, 2008, K. Matusiak (red.), Polska Agencja Rozwoju Przedsiębiorczości, Warszawa.

Materialy wewnetrzne Fundacji Akademickie Inkubatory Przedsiebiorczości w Warszawie.

Matusiak K.B., 2001, Uczelniany inkubator przedsiebiorczości, [w:] Edukacja dla rozwoju innowacyjnego w Polsce, J. Szabłowski (red.), Wydawnictwo KRUN, Warszawa-Białystok.

Matusiak K.B., 2010, Ośrodki innowacji i przedsiębiorczości w Polsce. Raport 2010, Polska Agencja Rozwoju Przedsiębiorczości, Warszawa.

Matusiak K.B., Zasiadły K., 2005, Rekomendacje dla Polski, [w:] Innowacyjna przedsiebiorczośt akademicka - snniatowe dośniadczenia, J. Guliński, K. Zasiadky (red.), Wydawnictwo PARP, Warszawa.

Ośrodki innowacii w Polsce. Raport 2009, 2009, K. Matusiak (red.), Wydawnictwo PARP, Warszawa-Łódź. 
Siemieniuk L., 2007, Funkcjonowanie Akademickich Inkubatorów Pręedsiębiorczości w zakeresie kreowania przedsiębiorczości studentów, [w:] Studia i co dalej... Sytuacja studentów na rynk.u pracy, M. Kruk (red.), Wydawnictwo Uniwersytetu w Białymstoku, Białystok.

Siemieniuk L., 2016, Academic Business Incubators as an Institutional Form of Academic Entrepreneurship Development in Poland, "Oeconomia Copernicana", vol. 7, issue 1.

Stawasz E. i in., 2009, Prz̨edsiębiorczośc akademicka - raport z. badania, Polska Agencja Rozwoju Przedsiębiorczości, Warszawa.

Tamowicz P., 2006, Przedsiębiorczość akademicka Spótki spin-off w Polsce, Polska Agencja Rozwoju Przedsiębiorczości, Warszawa.

Ustawa z. dnia 27 lipca 2005 r. Prawo o szkolnictwie wyższym, Dz. U. Nr 164, poz. 1365 z późn. zm. 